Al-Mana- ij: Jurnal Kajian Hukum Islam

Vol. XIII No. 1, Juni 2019, 1-13

p-ISSN 1978-6670 | e-ISSN 2579-4167

DOI: https://doi.org/10.24090/mnh.v0i1.2124

\title{
TRANSFORMASI HUKUM PIDANA ISLAM \\ DALAM TATA HUKUM INDONESIA
}

\author{
Makhrus Munajat \\ Fakultas Syari'ah dan Hukum UIN Sunan Kalijaga Yogyakarta \\ Jalan Laksda Adisucipto Yogyakarta 55281 \\ e-mail:makhrus_munajat@yahoo.co.id
}

\begin{tabular}{llllll}
\hline Submit & $:$ & 22 Januari 2019 & Diterima & $:$ & 13 Mei 2019 \\
Revisi & $:$ & 15 Maret 2019 & Terbit: & $:$ & 25 Juni 2019 \\
\hline
\end{tabular}

\section{Abstrak}

Bentuk formalisasi hukum pidana Islam di Indonesia masih dan selalu diperdebatkan dari segi legal formal atau tegaknya the Islamic values, artinya lebih dipentingkan aspek substansi ketimbang legal formalnya. Transformasi hukum pidana Islam adalah perubahan yang terjadi dalam penetapan hukum, baik yang menyangkut tentang jarimah ataupun sanksi karena dinamika waktu dan sosial. Jarimah dan sanksi adalah interkoneksitas antara hukum pokok (al-ahkām al-așliyyah) yang berisi larangan dan hukum pendukung (al-ahkām almuayyidah) yang berisikan sanksi. Model transformasi hukum pidana Islam di Indonesia adalah menjadikan hukum pidana Islam bersifat obyektif yang dapat diterima oleh masyarakat Indonesia, dengan tidak membedakan suku, adat, budaya dan agama. Obyektifikasi hukum pidana Islam di Indonesia dijadikan dasar pijakan bagi pembentukan hukum nasional yang masyarakatnya majemuk dengan ditawarkannya nilai-nilai universal, sehingga dapat diterima oleh seluruh warga negara tanpa mempersoalkan asal usul nilai tersebut.

Kata kunci: jarīmah, transformasi, konteks keindonesiaan, al-aḥkām al-aṣliyyah, alahkām al-muayyidah, obyektifikasi.

\section{Abstract}

The formalization of Islamic criminal law in Indonesia is still and always debated in terms of its legal rules or the establishment of Islamic values, meaning that the substance is more important than the formal rules. Transformation of Islamic criminal law is a change that occurs in the determination of law, both concerning the type of crime (jarimah) or its sanctions due to time and social dynamics. The criminal act (jarimah) and its sanctions are interconnection between the principal law (al-ahkām al-aṣliyyah) which contains the prohibition and supporting law (al-aḥkàm al-muayyidah) which contains sanctions. The model of the transformation of Islamic criminal law in Indonesia is to make Islamic criminal law a law that can be accepted by Indonesian people, by not distinguishing ethnicity, adat (tradition), culture and religion. The objectivity of Islamic criminal law in Indonesia is used as the basis for the formation of national laws whose pluralistic communities are offered universal values so that they can be accepted by all citizens without questioning the origin of the values.

Keywords: jarīmah, transformation, Indonesian context, al-aḥkām al-aṣliyah, al-alahkām al-muayyidah, objectification. 


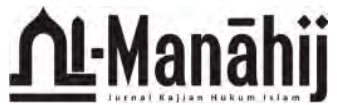

\section{A. Pendahuluan}

Upaya formalisasi syari'at Islam di Indonesia telah menjadi diskursus yang melelahkan, bahkan sebelum berdirinya negara Republik Indonesia benih perdebatan sudah muncul secara terbuka pada tahun 1940 ketika terjadi polemik antara Soekarno (nasionalis sekuler) versus Muhammad Natsir (nasionalis Islam). Soekarno berpendirian bahwa demi menjaga kemajuan suatu negara dan agama, negara dan agama harus dipisah, sedangkan M. Natsir berpendirian sebaliknya bahwa hubungan agama dan negara harus menjadi satu. Dengan kata lain, agama harus diurus oleh negara, sedangkan negara diurus berdasarkan ketentuan-ketentuan agama. ${ }^{1}$ Polemik itu merupakan kelanjutan dari perseteruan antara kebangsaan Jawa (politik dan agama harus terpisah) dan Serikat Islam (gerakan Islam Nasionalis) tahun 1918. Perdebatan tersebut bahkan masih berlanjut sampai sekarang, yakni dengan munculnya keinginan penegakan syari'at Islam dalam suatu negara secara legal formal dan penegakan syari'at Islam pada ranah substansinya, yaitu tegaknya the Islamic values. ${ }^{2}$ Dengan demikian, Islam diperjuangkan pada aspek dan nilai-nilai substantifnya bukan formalisasi simboliknya. $^{3}$

Polemik itu dilatarbekangi, bahwa Islam yang ajarannya mengandung prinsip-prinsip dasar kehidupan, termasuk persoalan politik dan hukum serta masalah kenegaraan, sejak awal sejarahnya tidak memberikan ketentuan yang pasti tentang bentuk dan konsep penegakan syari'at Islam dalam suatu negara. Di sinilah letak terjadinya berbagai penafsiran dan upaya untuk merealisasikannya.

Transformasi hukum Islam yang dilakukan para mujtahid dalam rangka penemuan dan penetapan hukum harus dilihat sebagai modal berharga, bukan sesuatu yang stagnan dan bukan perjuangan final. Penggalian huku melalui ijtihad selalu dan terus berproses sesuai dengan perubahan dan perkembangan serta realitas kehidupan. ${ }^{4}$ Sebagai konsekuensinya, diperlukannya ijtihad yang bersifat responsif, ${ }^{5}$ karena persoalan-persoalan baru terus berkembang sementara nașs telah berhenti

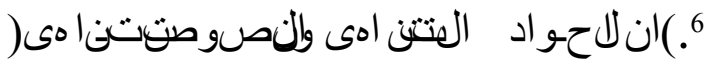
Upaya transformasi hukum pidana Islam dalam upaya pembaruan hukum pidana merupakan bagian dari tuntutan penerapan syari'at Islam di Indonesia. ${ }^{7}$ Meskipun adanya anggapan, bahwa hukum pidana Islam (al-fiqh al-jināyah $)^{8}$ adalah produk hukum yang out of date dan tidak humanis. Bahkan ada sebagian orientalis melihat sebagai sebuah hukum yang kejam, primitif dan konsepsi balas dendam. ${ }^{9}$ Kesan seperti itu muncul karena hukum pidana Islam tidak dilihat secara utuh atau parsial. Di balik persepsi negatif seperti di atas, ternyata banyak kalangan akademisi dan dunia hukum (Islam) memperhatikan dan mengkaji hukum pidana Islam, bahkan memberikan kontribusi pemikiran dalam rangka pembangunan hukum nasional.

Tawaran mengenai hukum Islam model Indonesia sebenarnya sudah banyak dikemukakan oleh pemikirpemikir Islam, seperti T.M. Hasbi AshShiddieqy dengan gagasan "Fikih Indonesia". 10 Hazairin memunculkan teori tentang "Mazhab Indonesia". ${ }^{11}$ Munawir Sjadzali mempunyail gagasan tentang "Kontekstualisasi- Hukum Islam di Indonesia". ${ }^{12}$ A. Qodri Azizy, mempunyai gagasan tentang "Positivisasi Hukum Islam di Indonesia. ${ }^{13}$ Moh. Mahfud MD mempunyai gagasan tentang "Hukum Islam berdasarkan Pancasila". ${ }^{14}$ Penulis sendiri mempunyai gagasan tentang "Hukum Pidana Islam dalam Konteks Keindonesiaan". Gagasan-gagasan tersebut merupakan upaya kontribusi secara maksimal bagi pembentukan hukum Nasional di setiap bidang dan bersifat umum. 
Pemikiran atau gagasan umat Islam Indonesia tentang penerapan hukum pidana Islam di Indonesia, setidaknya ada klaster pemikiran, yaitu pemikiran Islam modern dengan gagasan penerapan hukum Pidana Islam di Indonesia adalah nilai nilai substansi, yakni nilai keadilan dan universal, seperti pezina dilarang dan pelakunya dihukum, tetapi tidak harus dirajam, atau pencuri adalh bentuk kejahatan dan pelakunya harus dipidana, tetapi tidak harus dengan potong, hukuman disesuaikan dengan kondisi di Indonesia. Pemikiran ini adalah gagasan pemikiran Islam modern seperti NU, ICMI, Muhamaiyah dan MUI. Adapaun gagasan penerapan hukum pidana Islam di Indonesia harus normatif sebagaimana bunyi teks al-Quran, artinya legal formal. Gagasan ini diwakili oleh paham keagamaan yang ekstrim, seperti HTI. MMI, FPI.

Perdebatan penerapan hukum pidana Islam di Indonesia sampai sekarang belum final dan terus menyisakan masalah. Misalnya beragamnya pemikiran dan persepsi ormas-ormas Islam dalam menyikapi model penegakan hukum pidana Islam di Indonesia. ${ }^{15}$ Model dan format seperti apa yang dapat diterapkan dan bisa diterima oleh seluruh lapisan masyarakat Indonesia, tanpa Tmemandang Adan membedakan suku, adat, budaya dan agama. Permasalahan yang sesungguhnya harus segera dijawab adalah bagaimana agar hukum pidana-Islam dapat memberi kontribusi maksimal terhadap pembinaan dan pembentukan hukum pidana Nasional

\section{B. Transformasi Norma-norma Hukum Pidana Islam}

Transformasi hukum pidana Islam adalah perubahan yang terjadi dalam penerapan tindak pidana, pertanggungjawaban pidana maupun ketentuan pidana karena dinamika waktu dan sosial. Bentuk transformasi hukum pidana Islam terjadi karena adanya interkoneksitas antara hukum pokok (al-ahkām al-aṣliyyah), yakni adanya larangan berbuat jahat dan hukum pendukung (al-ahkām almuayyidah), yakni sanksi bagi yang melanggarnya dan ini sesuai dengan prinsip maqūssid al-syarī'ah. Transformasi hukum Islam menghimpun tiga pengertian yang tidak dapat dipisahkan antara satu dengan yang lain, yakni: Pertama, sesuatu itu berubah karena diperbarui, pada mulanya pernah ada dan pernah dialami. Kedua, sesuatu yang diperbarui adalah yang usang dan ketinggalan zaman, dan ketiga, sesutau yang diaktualkan dan ditransformasikan dalam bentuk kreasi baru. ${ }^{16}$

Perubahan mendasar dalam kehidupan manusia sesuai dengan perkembangan zaman selalu menuntut pembaruan, reformasi dan reformulasi rumusan hukum. Jika tidak, maka hukum yang ada tidak akan mampu melahirkan kemaslahatan bagi kehidupan manusia. Yang terjadi justru sebaliknya, hukum menjadi pengekang dalam kemajuan umat. Pertanyaannya adalah bagaimana cara melakukan perubahan, tetapi masih dalam batas-batas yang dibenarkan oleh Allah. ${ }^{17}$ Secara metodologis, upaya pemahaman ajaran syari'ah harus meliputi dua model pendekatan. ${ }^{18}$ Pertama pendekátan doktriner-normatif. Artinya memahami ajaran syari'ah yang menyangkut teks-teks yang datang dari Allah yang diyakini sebagai pedoman pokok kehidupan yang bersifat sakral dan transenden. Pemahaman terhadap suatu teks akan sangat dipengaruhi oleh banyak faktor, baik bahasa maupun konteks sosial dari teks itu sendiri. Bahkan sekarang semakin dirasakan pentingnya kajian hermeneutika hukum (legal hermeneutic) yang dalam kajian hukum konvensional kurang mendapat perhatian. ${ }^{19}$

Kedua pendekatan empirisinduktif, artinya pemahaman Al-Qur'an dan as-Sunnah tidak absolut, melainkan relatif, sesuai dengan sifat relatif manusia 


\section{凡L-Manāhij}

itu sendiri. ${ }^{20}$ Lebih lanjut ditegaskan hasil hukum dari suatu proses berijtihad melalui model logika sangat bersifat relatif, luwes, fleksibel dan sekaligus dipandang mampu mengikuti denyut jantung dan perkembangan umat dengan tetap berlandaskan pada prinsip yang telah ada. Model pendekatan empiris- historicalinduktif yang bercirikan dialectical logic sepadan dengan model kajian ilmu pengetahuan lainnya seperti dikenal di Barat dengan istilah scientific approach dengan hasil yang bersifat relatif.

Kedua model baik normatif maupun empirik mempunyai implikasi jauh terhadap teori-teori ijtihad yang berkembang selama ini, tidak jarang misalnya, sebagian mujtahid lebih menekankan pada pola pertama (normatif) dan tidak memberi perhatian pada pola kedua (empiris). Akibatnya, hasil ijtihad cenderung tidak membumi dan tidak menyentuh persoalan umat. Sebaliknya, sebagian mujtahid lebih menekankan pada pola kedua (empiris) dengan al-aql yang lebih dominan, baik dalam bentuk maṣlaḥah, istiḥsān, qiyās atau lainnya. Dengan alasan untuk menjawab persoalan riil di masyarakat, mujtahid model ini sering terjebak pada pola pragmatisme dan utilitarianisme yang justru membawa mereka semakin jauh dari ketentuan teks. $^{21}$

Penerapan hukum pidana Islam dalam sejarah setidaknya dapat dikelompokan menjadi tiga periode. Periode pertama, Periode Nabi, yakni Pada periode awal (daur al-tasyri ), syari'ah Islam identik dengan wahyu Allah dalam al-Qur'an ditambah Sunnah. Sunnah merupakan otoritas teks kedua setelah al-Qur'an yang berarti Nabi diakui sebagai suara otoritatif. Nabi dipandang sebagai penerima wahyu Tuhan atau șăhib al-syari’ah (pemilik syari'ah). Nabi secara efektif berperan sebagai pemegang otoritas wahyu pada periode awal Islam yang mempunyai otoritas penafsiran teksteks wahyu yang diterimanya dari Allah dalam bentuk al-Qur'an. Periode nabi, Syari'ah identik dengan hukum.

Periode kedua, periode ijtihad di mana syari'ah ini tidak lagi berfungsi sebagai hukum dalam arti bersifat langsung, melainkan berkembang menjadi sumber hukum. Pada tahap ini harus dibedakan antara syariah, pemahaman terhadap syariah, dan penerapan terhadap pemahaman syariah.

Pemahaman terhadap syari'ah dalam pemikiran hukum Islam pada umumnya disebut dengan istilah fikih. Adapun penerapan terhadap fikih tidak lain adalah pandangan relatif manusia terhadap ajaran syari'ah yang absolut disebut dengan istilah taţīqu ahkām alfiqh (penerapan terhadap hukum-hukum fikih), bukan tațīq al-syarī'ah (penerapan terhadap syariat). Definisi tersebut memberi pengertian bahwa fikih merupakan produk pemikiran manusia yang bersifat temporal, lokal, dan kontekstual. Lokalitas dan konstektualitas pada dasarnya merupakan sifat dasar dari fikih, dan ini yang membedakan dengan syari'ah

Periode ketiga, periode legislasi (daur al-taqnin). Pada periode ini, formalisasi syariah Islam sebenarnya adalah qānūn. Dengan demikian, penerapan syariah Islam (tațīq alsyari $\vec{a} a)$ sesungguhnya adalah penerapan terhadap keputusan atau hukum-hukum fikih (tatbìq ahkām al-fiqh) yang tidak lain adalah hasil ijtihad. Dengan demikian berbeda antara syari'ah, fikih maupun qānūn. Qānūn merupakan aspek yang paling jelas tentang formalisasi, sedangkan syariah Islam adalah aspek yang paling jelas tentang ajaran Tuhan. Jika aturan Tuhan diundangkan oleh negara, maka itu disebut qānūn, yang sifatnya relatif (̇annī).

Kontekstualisasi hukum pidana Islam dapat di lihat adanya pertimbangan suatu perbuatan dianggap kejahatan, yakni merugikan masyarakat, baik secara individu maupun kolektif. 
Perlindungan terhadap agama sama artinya dengan larangan orang merusak atau meninggalkan agama, sehingga penghinaan terhadap agama atau kepercayaan dikenai sanksi. Perlindungan terhadap jiwa berimplikasi terhadap penerapan hukuman bagi pelaku yang mengganggu jiwa seseorang. Oleh karena itu, hukum Islam melarang membunuh dan melukai anggota badan. Proteksi terhadap jiwa dalam hukum pidana Islam dibahas dalam jarīmah qișās diyat. ${ }^{22}$

Perlindungan terhadap keturunan diimplementasikan dengan adanya larangan berzina, karena perbuatan zina akan menjadikan kaburnya keturunan. Untuk mengantisipasi ketidakjelasan keturunan, maka hukum pidana Islam melarang berbuat zina.

Perbuatan yang dapat merugikan harta benda sangat dilarang oleh Islam dan pelakunya ditindak tegas. Oleh karena itu, pencurian, penipuan, penggelapan, dan penipuan timbangan termasuk perbuatan yang dilarang. Hukum pidana Islam menggolongkannya ke dalam hukum pidana pencurian dan hirābah (penyamunan) dan jarimah ta'zīr.

Kontekstualisasi norma-norma hukum pidana Islam tidak lepas dari persoalan kajian larangan dan ketentuan sanksi. Larangan melakukan kejahatan dalam Islam disebut dengan istilah $a l$ ahkām al-așliyyah (ajaran pokok) yakni hukum asal yang harus dipertahankan dalam bentuk larangan yang harus ditaati oleh seluruh komponen masyarakat. Tujuan larangan ini agar manusia terhindar dari madharat. Namun, ada kecenderungan tidak taat larangan kalau larangan tersebut tidak ada konsekuensi hukumnya. Oleh karena itu, dalam rangka mencapai tujuan dari maqāșid al-syarî'ah diperlukan hukum pendukung guna memaksa untuk mematuhi al-ahkām alașliyyah (ajaran pokok). ${ }^{23}$ Aturan pendukung itu disebut al-ahkām almu'ayyidah (hukum pendukung), yaitu sanksi-sanksi yang dikenakan kepada siapa saja yang tidak mentaati al-ahkām al-aṣliyyah (ajaran pokok).

Perbuatan dianggap delik (jarìmah) bila terpenuhi syarat dan rukun. Adapun unsur jarimah dapat dikategorikan menjadi dua, yaitu unsur umum. Artinya unsur-unsur yang harus terpenuhi pada setiap jarimah. Adapun yang termasuk dalam unsur umum jarimah adalah: Pertama, Unsur formil (al-rukn al-syar' $i$ ) yaitu adanya undangundang atau nașs. Artinya setiap perbuatan tidak dianggap melawan hukum dan pelakunya tidak dapat dipidana kecuali adanya nașs atau undang-undang yang mengatur sebelum perbuatan itu dilakukan. Hal ini sesuai dengan kaidah:

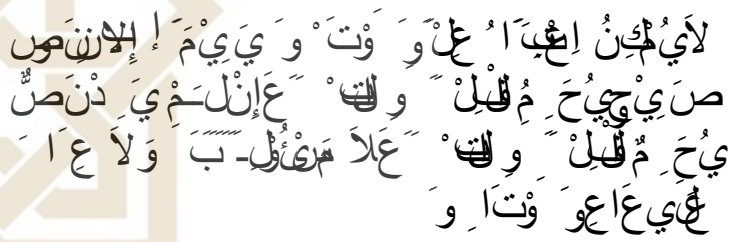

Tidak mungkin menganggap sikap berbuat atau sikap tidak berbuat sebagai suatu jarimah kecuali adanya nash tegas yang melarang perbuatan atau sikap tidak berbuat, jika tidak ada nash yang melarang untuk berbuat atau meninggalkan perbuatan, maka tidak ada pertanggungjawaban dan tidak ada pidana atas soseorang yang berbuat atau meninggalkan sesuatu perbuatan. ${ }^{24}$

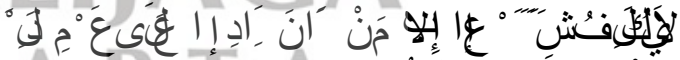

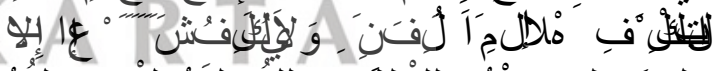

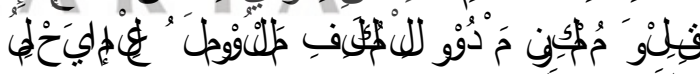

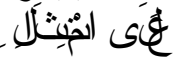

Menurut syara', seseorang tidak dapat dikenai takliff (pembebanan), kecuali orang yang mampu memahami dalil-dalil pembebanan dan menurut syara' pembebanan itu hanyalah pekerjaan yang mungkin dilakukan, disanggupi dan diketahui sehingga ia dapat melaksanakan. ${ }^{25}$ 
Kedua, unsur materiil (sifat melawan hukum). Artinya adanya tingkah laku seseorang yang membentuk jarimah, baik dengan sikap berbuat maupun sikap tidak berbuat. Unsur ini dalam hukum pidana Islam disebut dengan al-rukn al$m \bar{a} d \bar{\imath}$. Ketiga, Unsur moril (pelakunya mukallaf). Artinya, pelaku jarimmah adalah orang yang dapat dimintai pertanggungjawaban pidana terhadap jarimah yang dilakukannya. Dalam syari'at Islam, unsur moril disebut dengan al-rukn al-adabī. Adapun unsur khusus, artinya unsur-unsur yang harus terpenuhi pada jenis jarimah tertentu. $^{26}$

Penerapan hukum pidana Islam sangat dipengaruhi oleh dinamika waktu dan sosial. Contoh penerapan sanksi pezina. Di awal sejarahnya, sanksi pezina adalah cercaan dan hinaan (surat an-Nisa ayat 16), selanjutnya kurungan dalam rumah (surat an-Nisa ayat 15), tahap berikutnya hukuman dera (surat an-Nur ayat 2). Sementara hukum rajam yang sumbernya hadis Nabi diperdebatkan keautentikannya. Terlebih jika hukum rajam dikaitkan dengan surat an-Nisa ayat 25 dan surat al-Ahzab ayat 30. Dengan demikian, para fuqaha di samping menerapkan teori graduasi juga merasionalisasikan prinsip nasakh.

Ketentuan sanksi di atas menunjukkan adanya Tputusan \hukum yang berbeda yang dilakukan Nabi terhadap pezina. Artinya Nabi menerapkan hukum berdasarkan situasi dan kondisi, baik dari segi materi kejahatan maupun pelakunya. Maka dapat dipahami bahwa Nabi selalu berijtihad dalam menetapkan suatu hukum bagi pelaku tindak kejahatan demi tegaknya hukum yang berkeadilan.

Transformasi dalam tindak pidana pencurian, sebagaimana ketentuan alQuran surat al-Maidah ayat (38) pencuri dihukum hukum potong. Praktiknya, ketika ada pencuri yang mencuri buahbuahan dan dimakan di tempat, Rasulullah SAW meminta pencuri mengganti harga buah yang dimakan atau tidak menghukum apa-apa bagi pencuri buahbuahan yang dimakan di tempat jika diikhlaskan oleh pemiliknya. ${ }^{27}$ Umar ibn al-Khattab membebaskan hukum potong tangan pada musim paceklik. ${ }^{28}$ Sikap Umar bukan mengkhianati hukum Allah, melainkan semangat menangkap ruh syari'at Islam dengan pemahaman yang kontekstual.

Tindak pidana yang terkait dengan jiwa, dan dalam Islam dianggap hukum yang kejam dan konsepsi balasa denadam yakni qiṣass diyat, ${ }^{29}$ juga terjadi transformasi pemikiran. Ketentuan hukuman qiṣās diyat, ${ }^{30}$ diterapkan secara berkeseimbangan dan berkeadilan, seperti hukum qișās biasa berubah menjadi diyat, hukuman diyat menjadi dimaafkan dan apabila dimaafkan maka hukuman menjadi hapus.

\section{Kedudukan Hukum Islam dalam Tata Hukum Nasional}

Hukum nasional, sebagaimana negara-negara lain termasuk di barat, diperlukan berbagai sumber hukum. Karena itu dalam rangka pembinaan dan pembentukan hukum nasional perlu diperhatikan dan digali sumber-sumber yang ada di Indonesia, bahkan dalam situasi tertentu digunakan pula bahanbahan yang berasal dari mancanegara atau sumber yang berasal dari hukum internasional. Sumber-sumber yang berasal dari hukum yang ada di Indonesia adalah hukum Barat yang berasal dari Eropa Kontinental, hukum Adat yang beraneka ragam dan hukum agama yang ada di Indonesia. ${ }^{31}$

Pembinaan hukum nasional ini telah dilaksanakan dalam waktu yang lama. GBHN (Garis-Garis Besar Haluan Negara) dari tahun 1973 sampai dengan tahun 1998 sudah melakukan pembangunan hukum dan mengupayakan ke arah pembentukan hukum nasional. Dalam GBHN tahun 1999, yang merupakan produk masa reformasi, juga 
menegaskan arah kebijakan hukum nasional ini, yang antara lain menyatakan bahwa penataan sistem hukum nasional yang menyeluruh dan terpadu dengan mengakui dan menghormati hukum agama dan hukum adat serta memperbaharui perundang-undangan warisan kolonial. Pernyataan GBHN tersebut dapat dipahami bahwa pembangunan hukum nasional secara garis besar bersumber pada 1) hukum Agama, 2) hukum Adat, dan 3) hukum dari mancanegara, khususnya hukum Barat. ${ }^{32}$

Bahwa hukum Islam menjadi sumber hukum nasional bersama hukum barat dan hukum adat, bukan berarti ia menjadi hukum formal dengan bentuk sendiri yang eksklusif, kecuali sifatnya untuk melayani (bukan memberlakukan dengan imperatif) terhadap yang sudah berlaku sebagai kesadaran dalam kehidupan sehari-hari. Di sini hukum Islam harus diartikan sebagai sumber hukum materiil dalam arti menjadi bahan isi untuk sumber hukum formal. ${ }^{33}$ Untuk memperjelas masalah tersebut dapat dikemukakan, bahwa sumber hukum ada dua macam, yaitu sumber hukum materiil dan sumber hukum formal. Sumber hukum materiil adalah bahan-bahan hukum yang belum mempunyai bentuk tertentu dan belum mengikat, namun dapat dijadikan isichukum dengan bentuk tertentu agar menjadi mengikat. Sedangkan sumber hukum formal adalah sumber hukum yang telah mempunyai bentuk tertentu dan mengikat berlakunya sebagai hukum. Salah satu sumber hukum formal adalah undang-undang dalam arti meteriil yang terdiri dari berbagai peraturan perundang-undangan yang tersusun secara hirarkis. Selain itu ada juga undang-undang dalam arti formal (yang sudah mempunyai bentuk tertentu) yang menjadi bagian dari undang-undang dalam arti materiil. Artinya menjadi bagian dari peraturan perundangundangan yang masing-masing sudah mempunyai bentuk dan posisi hirarki tertentu. $^{34}$

Sistem hukum pidana nasional di Indonesia sesungguhnya hukum yang berdasarkan norma-norma agama yang dianut dan berlaku, karena negara memberi tempat kepada agama-agama yang dianut di Indonesia menjadi sumber hukum atau memberi bahan terhadap produk hukum nasional. Dengan demikian hukum Islam sebagai sumber hukum materiil (sumber bahan hukum) dan bukan harus menjadi sumber hukum formal (dalam bentuk tertentu menurut peraturan perundang-undangan). ${ }^{35}$

\section{Kontekstualisasi Norma-norma Hukum Pidana Islam di Indonesia}

Transformasi hukum pidana Islam di Indonesia ditempuh dengan jalan obyektifikasi hukum Islam, yaitu bagaimana penerapan hukum (pidana) Islam dalam suatu tatanan kehidupan bermasyakat, berbangsa dan bernegara harus bersifat obyektif dengan tidak membedakan suku, budaya, kelompok dan agama. Dalam obyektifikasi hukum Islam ditawarkan suatu jalan keluar agar nilainilai syari'ah Islam sebagai nilai universal tidak hanya diterima oleh umat Islam sendiri, melainkan oleh umat agama lain tanpa harus mempermasalahkan nilai-nilai itu berasal. Norma-norma hukum (pidana) Islam harus diterjemahkan dalam kategori-kategori yang obyektif sehingga dapat diterima oleh semua komponen bangsa (pihak). ${ }^{36}$ Dengan Obyektifikasi ini, hukum (pidana) Islam lebih membumi dalam merespon dan menyelesaikan persoalan-persoalan konkrit dan riil tentang hukum pidana yang ada dalam masyarakat Indonesia. Teori obyektifikasi hukum di atas sebagai upaya adanya konkritisasi hukum pidana Islam di Indonesia, yakni norma-norma hukum yang ada dan diakui keberadaanya oleh seluruh masyarakat Indonesia, termasuk hukum pidana Islam dapat dijadikan 


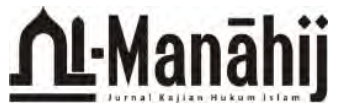

hukum konkrit (positif) melalui tahapan proses, formulasi dan legislasi.

Penerapan hukum pidana Islam di Indonesia harus memperhatikan sistem hukum nasional Indonesia, yaitu sistem hukum yang berlaku di Indonesia yang meliputi semua unsur hukum: isi, stuktur, budaya, sarana, peraturan perundangundangan dan semua sub unsurnya. ${ }^{37}$ Dalam membangun hukum di Indonesia, semua pihak seharusnya menghargai tata hukum nasional, mengingat Indonesia adalah negara kebangsaan yang relegius (relegious nation state) yang menjadikan agama sebagai dasar moral dan sumber hukum materil dalam penyelanggarakan negara. Negara Pancasila menggariskan empat prinsip dasar yang menjadi perhatian utama dalam penataan hukum nasional: pertama, hukum nasional harus menjamin integrasi dan keutuhan bangsa, oleh karena itu tidak boleh ada hukum yang diskriminasi berdasarkan ikatan primordial dan tidak boleh ada hukum yang mengancam disintegrasi bangsa. Kedua, hukum nasional harus mencerminkan asas demokratis dan nomokratis berdasarkan hikmah kebijaksanaan. Ketiga, hukum harus mendorong terciptanya keadilan sosial. Keempat hukum harus menghargai pluralitas, artinya tidak ada hukum publik yang didasarkan pada agama tertentu, sebab negara hukum || Pancasila mengharuskan tampilnya hukum yang menjamin toleransi hidup beragama yang beradab. $^{38}$

Di Indonesia, perjuangan sebagian umat Islam untuk memberlakukan "dasar negara" dan "Hukum Islam" sudah sejak lama dilakukan dan hasilnya adalah kompromi (modus vivendi) dalam bentuk negara Pancasila. Oleh karena perjuangan yang dilakukan adalah menegakkan amar ma'ruf nahi munkar adalah bukan membangun negara Islam melainkan membangun masyarakat yang Islami. Sebab setelah diperjuangkan secara konstitusional, negara Indonesia akhirnya dibangun sebagai negara Pancasila. Jika kita tak dapat memformalisasikan Islam dalam ranah hukum kita dapat memperjuangkan substansi ajaran Islam.

Nilai-nilai substansi ajaran Islam yang dapat diperjuangkan dan sudah pasti tidak akan ditolak oleh golongan lain karena sifatnya universal, yakni menegakkan keadilan, menegakkan hukum, membangun demokrasi, membangun kepemimpinan yang amanah, melindungi hak-hak asasi manusia, menjamin kebersamaan dan sikap toleransi. Nilai-nilai tersebut dapat dijadikan sebagai sumber hukum dan jalinan yang eklektik dengan sumber hukum lainnya untuk kemudian dilahirkan hukum nasional, itulah yang disebut hukum Islam berdasarkan Pancasila. ${ }^{39}$

Transformasi hukum pidana Islam di Indonesia dilakukan dengan mengakomodir norma-norma hukum pidana yang ada di dalam al-Quran ke dalam bahasa undang-undang. Artinya, perbuatan yang dianggap jarimah dalam al-Qur'an oleh undang-undang dimasukan sebagai tindak pidana dan pelakunya dapat dimintai pertanggungjawaban pidana. Contoh jarimah zina telah diatur Al-Quran tentang ketentuan tindak pidana dan pidananya (QS. al-Isra' ayat: 32 dan an-Nur ayat: 2). Jarimah zina dalam konteks /hukum | pidána di Indonesia disebut sebagai "Tindak Pidana Perzinaan" dan pelakunya dapat dipidana sebagaimana diatur dalam Pasal 284 KUHP. ${ }^{40}$ Jarimah qażf yang diatur dalam al-Quran surat an-Nur ayat: 4, dalam hukum positif dirumuskan dalam KUHP sebagai delik pencemaran nama baik dan pelakunya dapat dipidana sebagaimana diatur dalam Pasal 310 KUHP. Jarimah as-sariqah yang diatur dalam Al-Quran surat an-Mā'idah ayat: 38, oleh hukum positif dirumuskan dalam KUHP sebagai delik pencurian. Jarimah al-hirābah dalam hukum pidana Islam diatur dalam al-Quran surat an-Mā'idah ayat: 33, hukum positif dirumuskan dalam KUHP 
sebagai delik pencurian dengan kekerasan, bahkan dalam aturan lain dikategorikan sebagai tindak pidana "terorisme" sebagaimana diatur dalam Undang-Undang Nomor:15 Tahun 2003 tentang penetapan Perpu Nomor: 1 tahun 2002 tentang Pemberantasan Tindak Pidana Terorisme menjadi UU. ${ }^{41}$ Jarimah al-baghyu yang telah diatur dalam alQuran surat al-Hujurāt ayat: 9, oleh hukum positif dimasukan sebagai tindak pidana makar sebagaimana diatur dalam KUHP Pasal $104^{42}$ dan $107^{43}$. Jarimah Riddah yang disebutkan dalam al-Quran sebagai bentuk ketidakistiqamahan (tidak konsisten) dalam beragama diatur dalam surat al-Baqarah ayat: 217 , oleh KUHP ${ }^{44}$ dimasukan sebagai tindak pidana dan juga diatur dalam UU Nomor 1/PNPS $/ 1965^{45}$ tentang: Pencegahan Penyalahgunaan dan atau Penodaan Agama. Demikian jarimah qișāṣ diyat yang diatur dalam al-Quran surat al-Baqarah ayat 178-179, oleh hukum positif dianggap sebagai tindak kejahatan terhadap jiwa manusia yang diatur dalam pasal 338-350 KUHP. Meskipun RUU KUHP tidak ada diktum yang berbunyi bahwa pelaku pembunuhan dapat dikenakan hukum qișās, akan tetapi di Indonesia dikenal adanya hukuman mati sebagai alternatif terakhir (hukuman khusus atau eksepsional). Prinsip ini termasuk kolaborasi A dengan S doktrin maqāșid al-syarī'ah, bahwa tujuan dari hukum adalah merelaisir kemaslahatan umat manusia. ${ }^{46}$

Dalam rangka pembaruan hukum pidana Islam di Indonesia selalu diupayakan agar rancangan undangundang tentang KUHP mampu mengakomodir dan memperjuangkan masuknya nilai-nilai hukum Islam dalam konteks perundang-undangan di Indonesia. Upaya mengintegrasikan hukum pidana Islam ke dalam pembentukan hukum nasional pada tahapan penerapan secara substansif, yakni jarimah zina, qażf, sariqah, hirābah, baghy, riddah dan qișāș diyat, adalah perbuatan yang tidak sesuai dengan prinsip dan moralitas Islam dan dimasukan sebagai suatu jarimah dan pelakunya diancam dengan hukuman. ${ }^{47}$ Oleh karena jarimmah-jarimah tersebut telah dianggap sebagai suatu kejahatan (tindak pidana) dalam hukum pidana di Indonesia dan pelakunya dapat dikenai sanksi. Proses ini menurut peneliti merupakan upaya strategis legislasi hukum Islam yang bersifat bertahap dan sejalan dengan kaidah:

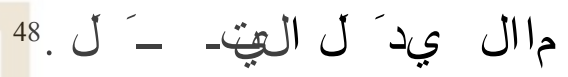

Sesuatu yang tidak dapat dicapai seluruhnya jangan ditinggalkan seluruhnya.

\section{E. Penutup}

Transformasi hukum pidana Islam adalah perubahan yang terjadi dalam penerapan tindak pidana, pertanggungjawaban pidana maupun ketentuan pidana karena dinamika waktu dan sosial. Bentuk transformasi hukum pidana Islam terjadi karena adanya interkoneksitas antara hukum pokok (alahkām al-aṣliyyah), yakni adanya larangan berbuat jahat dan hukum pendukung (al-aḥkām al-muayyidah), yakni sanksi bagi yang melanggarnya.

Kontekstualisasi hukum pidana Islam di- Inđonesia mempertimbangkan model obyektifikasi hukum, yakni menjadikan hukum pidana Islam bersifat obyektif sehingga dapat diterima oleh seluruh lapisan masyarakat Indonesia, dengan tidak membedakan suku, adat, budaya dan agama. Obyektifikasi hukum pidana Islam di Indonesia dijadikan landasan disamping hukum Islam secara resmi menjadi sumber hukum Nasional juga dijadikan dasar pijakan bagi pembentukan hukum nasional yang masyarakatnya majemuk dengan ditawarkannya nilai-nilai universal, seperti nilai keadilan dan kesamaan di depan hukum, sehingga nilai-nilai tersebut diterima oleh seluruh warga negara tanpa 


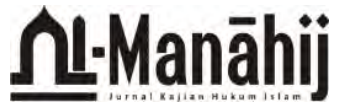

mempersoalkan asal usul dari nilai tersebut.

Model transformasi norma-norma hukum pidana Islam di Indonesia, secara substansial mengacu kepada prinsipprinsip syari'ah, yakni hukum yang berkeadilan dan berkeseimbangan antara kejahatan dan sanksi, antara si korban dan

${ }^{1}$ Moh. Mahfud MD, Hukum dan PilarPilar Demokrasi (Yogyakarta: Gama Media, 1999), 55.

${ }^{2}$ Monouchehr Paydar, Aspects of Islamic State Religious Norms and Political Realities, ed. M. Maufur (Yogyakarta: Fajar Pustaka Baru, 2003), vii.

${ }^{3}$ Moh. Mahfud MD, Perdebatan Hukum Tata Negara Paska Amandemen Konstitusi (Jakarta: LP3ES, 2007), 244.

4 Yudian Wahyudi, is Islamic Law Secular? A Critical Study of Hasan Hanafi's Legal Philosophy (Yogyakarta: Nawesea, 2005), 32.

Asjmuni A. Rahman, "Sorotan Terhadap Berbagai Masalah Sekitar Ijtihad," in Pidato Pengukuhan Guru Besar (Yogyakarta: IAIN Sunan Kalijaga, 1996).

6 Muhammad Abū Zahrah, Tārīkh alMażāhib al-Islāmiyyah, Juz 1 (Cairo: Dār al-Fikr, n.d.), 5.

${ }^{7}$ Makhrus Munajat, Dekonstruksi Hukum Pidana Islam (Yogyakarta: Logung Pustaka, 2004), v.

8 Jināyah dalam pemikiran sebagian fuqaha mempunyai pengertian yang sama dengan istilah jarīmah. Jināyah secara etimologi berasal dari kata janā berarti memetik. Janā juga murādif dengan irtikāba zanban artinya berbuat dosa, Ahmad Warsun Munawwir, Al-Munawwir: Kamus Arab-Indonesia (Yogyakarta: PP. Al-Munawwir, 1988) 233. Abd. Al-Qadir 'Awdah berpendapat bahwa jināyah artinya "perbuatan yang dilarang syara', baik berkenaan dengan jiwa, harta atau lainnya". Adapun istilah jarimah menurut alMawardi mengandung pengertian laranganlarangan syara' yang diancam olah Allah dengan hukum hadd atau ta'zīr. Sementara al-Sayid Sābiq mendefinisikan jināyah sebagai berikut "segala tindakan yang dilarang oleh syari'at untuk dilakukan". Perbuatan yang dilarang ialah setiap perbuatan yang bila dilakukan menimbulkan bahaya nyata terhadap agama, jiwa, akal, harga diri dan harta benda. Abd al-Qadīr Audah, al-Tasyrī' al-Jinā' '̄' al-Islāmī, Juz 1 (Beirut: Dār al-Fikr, 1963) 63. Abu Hasan al-Māward̄̄, al-Ahkām alSulțāniyyah wa al-Wilāyah al-Dīniyyah (Beirut: Dār al-Kutub al-'Ilmiyyah, 1978), 219. Al-Jurjān̄̄, al-Ta rīfāt (Beirut: Dār al-Fikr, n.d.), 70. Al- si pelaku. Transformasi hukum pidana Islam dalam konteks keindonesiaan telah terakomodir pada formulasi hukum, yakni perbuatan yang dianggap jarimah maka dalam KUHP disebut sebagai perbuatan pidana.

\section{Catatan Akhir:}

Sayyid Sābiq, Fiqh al-Sunnah, Juz 2 (Beirūt: Dār al-Fikr, 1972), 427. Ahmad Hanafi, Asas-Asas Hukum Pidana Islam (Jakarta: Bulan Bintang, 1976), 1.

9 Anwar Haryono, Hukum Islam: Keluasan Dan Keadilannya (Jakarta: Bulan Bintang, 1968), 151.

10 T.M. Hasbi Ash-Shiddieqy, Syari'at Islam Menjawab Tantangan Zaman (Jakarta: Bulan Bintang, 1966), 43.

11 Hazairin, Tujuh Serangkai Tentang Hukum (Jakarta: Bina Aksara, 1985), 153.

12 Munawir Sjadzali, Polemik Reaktualisasi Ajaran Islam (Jakarta: Pustaka Panjimas, 1988), 5.

13 A. Qodry Azizy, Hukum Nasional: Eklektisisme Hukum Islam Dan Hukum Umum (Jakarta: Penerbit Teraju, 2004), 298.

${ }^{14}$ Mahfud MD, Perdebatan Hukum Tata Negara Paska Amandemen Konstitusi, 242-4.

15 Nurkholis Setiawan, "Kontribusi Hukum Pidana Islam Dalam Pembentukan Hukum Nasional (Penelusuran, Pemetaan, Dan Pengujian Respon Serta Pemikiran Majelis Mujahidin Indonesia (MMI), Hizbut Tahrir Indonesia (HTI), Front Pembela Islam (FPI), Majlis Ulama Indonesia (MUI), Muhammad" (Jakarta: LIPI, 2006), 74

U 16 Rifyal Ka'bah and Bustami Sa'id, Reaktualisasi Ajaran Islam (Pembaharuan Agama Visi Modernis dan Pembaharuan Agama Visi Salaf (Jakarta: Minaret, 1987), 52.

17 Akh. Minhaji, "Tradisi Islah dan Tajdid dalam/Hukum Islam," Profetika: Jurnal Studi Hukum Islam, no. Yogyakarta (2001), 246-7.

${ }^{18}$ Minhaji, 248.

${ }^{19}$ Minhaji.

20 Akh. Minhaji, "Perubahan Sosial Dalam Perspektif Sejarah Hukum Islam (Kerangka Metodologi)," Dinamika: Jurnal Dialektika Peradaban Islam, no. Yogyakarta (2003), 20-1.

21 Akh. Minhaji, "Tradisi Ijtihad Dalam Islam: Dulu, Kini dan Masa Mendatang," Jurnal Hukum, no. June (2001), 15.

22 Jarimah qișās diyat adalah tindak pidana yang berkaitan dengan pelanggaran terhadap jiwa atau anggota tubuh seseorang. Hukuman terhadap tindak pidana ini adalah kisas, 
(yaitu memberikan perlakuan yang sama kepada terpidana sesuai dengan tindak pidana yang ia lakukan, misalnya membunuh dibalas dengan hukuman mati) atau diyat yaitu ganti rugi dengan harta melalui keputusan hakim, Al-Jurjān̄i, AlTa 'rīfât, 354.

23 Satria Effendi M. Zein, "Kejahatan Dalam Harta Dalam Perspektif Hukum Islam," in Hukum Pidana Islam di Indonesia: Peluang, Prospek Dan Tantangan, ed. Satria Effendi M. Zein (Jakarta: Pustaka Firdaus, 2001), 111. Musțafā Al-Zarqā, al-Fiqh al-Islāmī fì Saubih alJadìd, Juz 2 (Damascus: Matba'ah Tarafain, 1965), 114.

${ }^{24}$ Zein, "Kejahatan Dalam Harta Dalam Perspektif Hukum Islam."

${ }^{25}$ Audah, al-Tasyrì' al-Jinā' '̄’' al-Islāmī, 87.

${ }^{26}$ Audah, 110-1.

27 Abū Yūsuf, al-Radd 'alā Siyār AlAuzā'T̄ (Cairo: Dār al-Qalam, 1357), 50.

${ }^{28} \mathrm{Ibn}$ al-Qayyim al-Jauziyyah, I'lām alMuwaqqi'ìn 'an Rabb al-'Ālamin, Juz 3 (Beirut: Dār al-Fikr, 1977), 22. Subhi Mahmasani, Falsafah al-Tasyrī' fì al-Islām (Cairo: Dār alQalam, 1945), 167.

29 Qiṣāṣ ialah perbuatan yang diancam dengan hukum qisas atau semisal dengan perbuatan yang dilakukan oleh terpidana, alJurjānī, al-Ta 'rîfāt, (Beirut: Dār al-Fikr, t.t.), hlm. 173. Adapun yang dimaksud dengan diyat ialah hukuman ganti rugi dengan cara membayar sejumlah harta benda yang diberikan terpidana kepada si korban atau walinya berdasarkan keputusan hakim, Sābiq, Fiqh al-Sunnah, 107.

${ }^{30}$ Qiṣạs diyat ada beberapa jenis, yaitu (a) membunuh sengaja (al-qatl al-amd), (b) membunuh semi sengaja (al-qatl sibh al-amd), (c) membunuh keliru (al-qatl al-khata'), (d) penganiayaan sengaja (al-jarh al-amd), (e) penganiayaan salah (al-jarh al-khața'). Qișāṣ diyat adalah suatu kejahatan terhadap jiwa (menghilangkan nyawa) dan anggota badan (pelukaan) yang diancam dengan hukuman serupa atau hukum ganti rugi dari si pelaku atau ahlinya kepada si korban atau walinya. Kejahatan yang masuk golongan ini dalam hukum pidana barat biasa dikenal sebagai tindak pidana terhadap tubuh dan jiwa. Dalam hukum pidana Islam, yang termasuk dalam jarimah qișạs diyat ini adalah (1) pembunuhan dengan sengaja; (2) pembunuhan semi sengaja; (3) menyebabkan matinya orang karena kealpaan atau kesalahan; (4) penganiayaan dengan sengaja; dan (5) menyebabkan orang luka karena kealpaan atau kesalahan. Audah, al-Tasyrī, al-Jinā '̄' al-Islāmī, 149-53.

31 Azizy, Hukum Nasional: Eklektisisme Hukum Islam dan Hukum Umum, 137-8.
${ }^{32}$ Azizy, 208.

${ }^{33}$ Mahfud MD, Perdebatan Hukum Tata Negara Paska Amandemen Konstitusi, 240-2.

${ }^{34}$ Mahfud MD.

${ }^{35}$ Mahfud MD.

36 Kuntowijoyo, Identitas Politik Umat Islam (Bandung: Mizan, 1997), 70-1.

${ }^{37}$ Moh. Mahfud MD, Membangun Politik Hukum, Menegakkan Konstitusi (Jakarta: LP3ES, 2006), 20-1. Mahfud MD, Perdebatan Hukum Tata Negara Paska Amandemen Konstitusi, 23940.

38 Mahfud MD, Membangun Politik Hukum, Menegakkan Konstitusi, 22.

${ }^{39}$ Mahfud MD, Perdebatan Hukum Tata Negara Paska Amandemen Konstitusi, 243-4.

${ }^{40}$ Pasal 284 KUHP adalah delik aduan yang tidak memungkinkan perbuatan itu dipidana jika tidak ada yang mengadukan dari pihak yang dirugikan (suami atau istri yang dikhianati pasangannya). Pandangan ini yang bertentang dengan prinsip dasar maqāṣid al-syarī'ah. Upaya ke arah kontribusi pemikiran hukum pidana Islam secara maksimal tentang delik perzinaan tela dirumuskan dalam RUU KUHP 2008 Bab XVI: tentang Tindak Pidana Kesusilaan, tepatnya pada bagian keempat, zina dan perbuatan cabul, Pasal 485 ayat (1) Dipidana karena zina, dengan pidana paling lama 5 (lima) tahun:

a. Laki-laki yang berada dalam ikatan perkawinan melakukan persetubuhan dengan perempuan yang bukan istrinya.

b. Perempuan yang berada dalam ikatan perkawinan melakukan persetubuhan dengan laki-laki yang bukan suaminya.

c. Laki-laki yang tidak dalam ikatan perkawinan melakukan persetubuhan dengan perempuan, padahal diketahui bahwa perempuan tersebut berada dalam ikatan perkawinan: II

d. Perempuan yang tidak dalam ikatan perkawinan melakukan persetubuhan dengan laki-laki, padahal diketahui bahwa lakilaki tersebut berada dalam ikatan perkawinan; atau

e. Laki-laki dan perempuan yang masing-masing tidak terikat dalam perkawinan yang sah melakukan persetubuhan.

${ }^{41}$ Pasal 6 Undang-Undang Nomor:15 Tahun 2003 menegaskan " Setiap orang yang dengan sengaja menggunakan kekerasan atau ancaman kekerasan menimbulkan suasana teror atau rasa takut terhadap orang secara meluas atau menimbulkan korban yg bersifat masal, dengan cara merampas kemerdekaan atau hilangnya nyawa dan harta benda orang lain atau mengakibatkan kerusakan atau kehancuran terhadap obyek-obyek vital yang strategis atau 
lingkungan hidup atau fasilitas publik atau fasilitas internasional, dipidana dengan pidana mati atau penjara seumur hidup atau pidana penjara paling singkat 4 (empat) tahun dan paling

42 Pasal 104 KUHP berbunyi: "Makar yang dilakukan dengan maksud membunuh Presiden yang sedang memerintah atau dengan maksud menjadikan Presiden tidak mampu memerintah dihukum dengan hukuman mati, atau hukuman penjara seumur hidup atau penjara selama-lamanya dua puluh tahun".

43 Pasal 107 ayat (1) KUHP berbunyi:

"Makar yang dilakukan dengan maksud akan meruntuhkan pemerintahan dihukum dengan hukuman penjara selama-lamanya lima belas tahun". Pasal 107 ayat (2) KUHP berbunyi: "Pemimpin dan pengatur makar yang dimaksudkan dalam ayat (1) dihukum dengan hukuman penjara seumur hidup atau penjara selama-lamanya dua puluh tahun".

${ }^{44}$ Pasal 156a KUHP berbunyi: "Dipidana dengan pidana penjara selama-lamanya lima tahun barangsiapa dengan sengaja di muka umum mengeluarkan perasaan atau melakukan perbuatan:

a. yang pada pokoknya bersifat permusuhan, penyalahgunaan atau penodaan terhadap suatu agama yang dianut di Indonesia;

\section{DAFTAR PUSTAKA}

al-Jauziyyah, Ibn al-Qayyim. I'tām alMuwaqqi'̄̄n 'an Rabb al-'Ālamīn. Beirut: Dār al-Fikr, 1977.

al-Jurjān̄̄. Al-Ta 'rîfāt. Beirut: Dār al-Fikr, n.d.

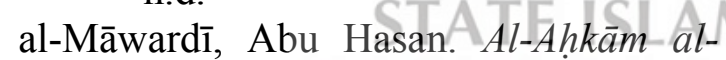
Sultāniyyah wal al-Wiläyah alDiniyyah. Beirut: Dār al-Kutub al'Ilmiyyah, 1978.

al-Zarqā, Musțafā. Al-Fiqh al-Islāmī fì Śaubih al-Jadīd. Juz 2. Damascus: Matba'ah Tarafain, 1965.

Ash-Shiddieqy, T.M. Hasbi. Syari'at Islam Menjawab Tantangan Zaman. Jakarta: Bulan Bintang, 1966.

Audah, Abd al-Qadīr. Al-Tasyrī' alJinā' '̄' al-Islāmì. Juz 1. Beirut: Dār al-Fikr, 1963.

Azizy, A. Qodry. Hukum Nasional: Eklektisisme Hukum Islam Dan b. dengan maksud agar supaya orang tidak menganut agama apapun juga, yang bersendikan ke-Tuhanan Yang Maha Esa.

45 Pasal 1 UU Nomor 1/PNPS /1965

berbunyi: "Setiap orang dilarang dengan sengaja di muka umum menceritakan, menganjurkan atau mengusahakan dukungan umum, untuk melakukan penafsiran tentang sesuatu agama yang dianut di Indonesia atau melakukan kegiatan-kegiatan keagamaan yang menyerupai kegiatan-kegiatan keagamaan dari agama itu, penafsiran dan kegiatan mana menyimpang dari pokok-pokok ajaran agama itu".

${ }^{46}$ Muhammad Khalid Mas'ud, Filsafat Hukum Islam Dan Perubahan Sosial, ed. Yudian Wahyudi (Surabaya: Al-Ikhlas, 1995), 225.

47 Arskal Salim, "Politik Hukum Pidana Islam Di Indonesia: Eksistensi Historis, Kontribusi Fungsional Dan Prospek Masa Depan," in Pidana Islam Di Indonesia: Peluang Prospek dan Tantangan (Jakarta: Pustaka Firdaus, 2001), 259.

48 Abd al-Hamīd Hakīm, Mabād $\bar{\imath}^{\prime}$ Awwaliyyah: Ușūl Al-Fiqh wa al-Qawā'id alFiqhiyyah (Jakarta: Maktabah Sa'adiyyah Putra, n.d.), 269.

Hukum Umum. Jakarta: Penerbit Teraju, 2004.

Hakīm, Abd al-Hamīd. Mabādì ' Awwaliyyah: Ușūl al-Fiqh wa alQawā'id al-Fiqhiyyah. Jakarta: Maktabah Sa'adiyyah Putra, n.d.

Hanafi, Ahmad. Asas-Asas Hukum Pidana Islam. Jakarta: Bulan Bintang, 1976.

Haryono, Anwar. Hukum Islam: Keluasan dan Keadilannya. Jakarta: Bulan Bintang, 1968.

Hazairin. Tujuh Serangkai Tentang Hukum. Jakarta: Bina Aksara, 1985.

Ka'bah, Rifyal, and Bustami Sa'id. Reaktualisasi Ajaran Islam (Pembaharuan Agama Visi Modernis dan Pembaharuan Agama Visi Salaf. Jakarta: Minaret, 1987.

Kuntowijoyo. Identitas Politik Umat Islam. Bandung: Mizan, 1997. 
Mahfud MD, Moh. Hukum dan PilarPilar Demokrasi. Yogyakarta: Gama Media, 1999.

Mahfud MD, Moh. Membangun Politik Hukum, Menegakkan Konstitusi. Jakarta: LP3ES, 2006.

Mahfud MD, Moh. Perdebatan Hukum Tata Negara Paska Amandemen Konstitusi. Jakarta: LP3ES, 2007.

Mahmasani, Subhi. Falsafah al-Tasyrī' fì al-Islām. Cairo: Dār al-Qalam, 1945.

Mas'ud, Muhammad Khalid. Filsafat Hukum Islam dan Perubahan Sosial. Edited by Yudian Wahyudi. Surabaya: Al-Ikhlas, 1995.

Minhaji, Akh. "Perubahan Sosial dalam Perspektif Sejarah Hukum Islam (Kerangka Metodologi)." Dinamika: Jurnal Dialektika Peradaban Islam, no. Yogyakarta (2003).

Minhaji, Akh. "Tradisi Ijtihad dalam Islam: Dulu, Kini dan Masa Mendatang." Jurnal Hukum, no. June (2001).

Minhaji, Akh. "Tradisi Islah dan Tajdid dalam Hukum Islam." Profetika: Jurnal Studi Hukum Islam, no. Yogyakarta (2001).

Munajat, Makhrus. Dekonstruksi Hukum Pidana Islam.TEYogyakarta: Logung Pustaka, 2004.

Munawwir, Ahmad Warsun. AlMunawwir: Kamus ArabIndonesia. Yogyakarta: PP. AlMunawwir, 1988.

Paydar, Monouchehr. Aspects of Islamic State Religious Norms and Political Realities. Edited by M. Maufur. Yogyakarta: Fajar Pustaka Baru, 2003.

Rahman, Asjmuni A. "Sorotan Terhadap
Berbagai Masalah Sekitar Ijtihad.” In Pidato Pengukuhan Guru Besar. Yogyakarta: IAIN Sunan Kalijaga, 1996.

Sābiq, al-Sayyid. Fiqh al-Sunnah. Juz 2. Beirut: Dār al-Fikr, 1972.

Salim, Arskal. "Politik Hukum Pidana Islam di Indonesia: Eksistensi Historis, Kontribusi Fungsional dan Prospek Masa Depan." In Pidana Islam di Indonesia: Peluang Prospek dan Tantangan. Jakarta: Pustaka Firdaus, 2001.

Setiawan, Nurkholis. "Kontribusi Hukum Pidana Islam dalam Pembentukan Hukum Nasional (Penelusuran, Pemetaan, dan Pengujian Respon Serta Pemikiran Majelis Mujahidin Indonesia (MMI), Hizbut Tahrir Indonesia (HTI), Front Pembela Islam (FPI), Majlis Ulama Indonesia (MUI), Muhammad.” Jakarta: LIPI, 2006.

Sjadzali, Munawir. Polemik Reaktualisasi Ajaran Islam. Jakarta: Pustaka Panjimas, 1988.

Wahyudi, Yudian. is Islamic Law Secular? A Critical Study of Hasan Hanafi's Legal Philosophy. Yogyakarta: Nawesea, 2005.

Yūsuf, Abū. al-Radd 'alā Siyār al-Awza'̄̄. Cairo: Dār al-Qalam, 1357.

Zahrah, 『Muhammad Abū. Tārīkh alMażăhib al-Islāmiyyah. Juz 1. Cairo: Dār al-Fikr, n.d.

Zein, Satria Effendi M. "Kejahatan dalam Harta dalam Perspektif Hukum Islam." In Hukum Pidana Islam di Indonesia: Peluang, Prospek dan Tantangan, edited by Satria Effendi M. Zein. Jakarta: Pustaka Firdaus, 2001. 


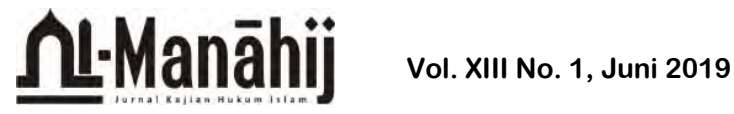

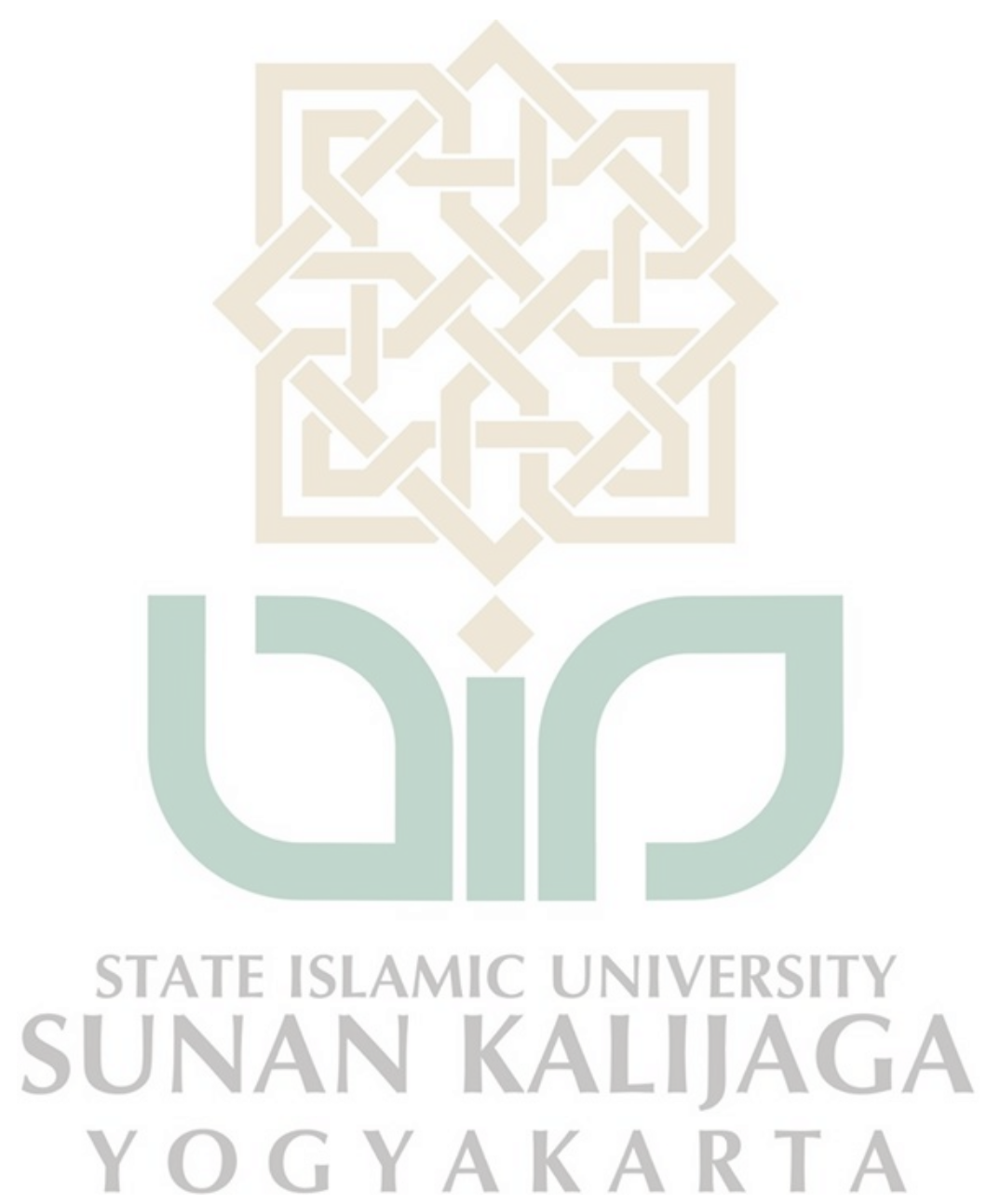

